\title{
Synthesis of carbon-11-labeled imidazopyridine- and purine- thioacetamide derivatives as new potential PET tracers for imaging of nucleotide pyrophosphatase/phosphodiesterase 1 (NPP1)
}

\author{
Mingzhang Gao, Min Wang, Qi-Huang Zheng* \\ Department of Radiology and Imaging Sciences, Indiana University School of Medicine, 1345 West $16^{\text {th }}$ Street, Room 202, \\ Indianapolis, IN 46202, USA
}

*Corresponding author. Tel.: +1 317-278-4671. Fax: +1 317-278-9711. E-mail address: qzheng@iupui.edu.

This is where the receipt/accepted dates will go; Received Month XX, 2016; Accepted Month XX, 2016 [BMCL RECEIPT]

\begin{abstract}
The target tracer carbon-11-labeled imidazopyridine- and purine-thioacetamide derivatives, $N-\left(3-\left[{ }^{11} \mathrm{C}\right] \mathrm{methoxy}-4-\right.$ methoxyphenyl)-2-((5-methoxy-3H-imidazo[4,5-b]pyridin-2-yl)thio)acetamide $\left(3-\left[{ }^{11} \mathrm{C}\right] 4 \mathbf{a}\right)$ and $N$-(4- $\left[{ }^{11} \mathrm{C}\right]$ methoxy-3-methoxyphenyl)-2((5-methoxy-3H-imidazo[4,5-b]pyridin-2-yl)thio)acetamide $\quad\left({ }^{4-}\left[{ }^{11} \mathrm{C}\right] \mathbf{4 a}\right) ; \quad 2-\left((6\right.$-amino-9H-purin-8-yl)thio $)-N$ - $\left(3-\left[{ }^{11} \mathrm{C}\right] \mathrm{methoxy}-4-\right.$ methoxyphenyl)acetamide $\left(3-\left[{ }^{11} \mathrm{C}\right] \mathbf{8 a}\right)$ and $2-\left(\left(6\right.\right.$-amino- $9 H$-purin-8-yl)thio)- $N-\left(4-\left[{ }^{11} \mathrm{C}\right]\right.$ methoxy-3-methoxyphenyl)acetamide $\left(4-\left[{ }^{11} \mathrm{C}\right] \mathbf{8 a}\right)$, were prepared by $O-\left[{ }^{11} \mathrm{C}\right]$ methylation of their corresponding precursors with $\left[{ }^{11} \mathrm{C}_{\mathrm{CH}_{3}} \mathrm{OTf}\right.$ under basic condition $(2 \mathrm{~N} \mathrm{NaOH})$ and isolated by a simplified solid-phase extraction (SPE) method in 50-60\% radiochemical yields based on $\left[{ }^{11} \mathrm{C}\right] \mathrm{CO}_{2}$ and decay corrected to end of bombardment (EOB). The overall synthesis time from EOB was 23 min, the radiochemical purity was $>99 \%$, and the specific activity at end of synthesis (EOS) was $185-555 \mathrm{GBq} / \mu \mathrm{mol}$.
\end{abstract}

Keywords: Carbon-11-labeled imidazopyridine- and purine-thioacetamide derivatives; Nucleotide pyrophosphatase/phosphodiesterase 1 (NPP1); Positron emission tomography (PET); Type 2 diabetes; Brain cancers.

The enzyme family of human nucleotide pyrophosphatases/phosphodiesterases (NPPs), existing both as membrane proteins with an extracellular active site and as soluble proteins in body fluids, is a class of dimeric enzymes that catalyze the hydrolysis of phosphate diester bonds, and it consists of seven subtypes (NPP1-7). ${ }^{1}$ NPP1 is a membrane glycoprotein involved in the hydrolysis of extracellular nucleotides, and NPP1 is a vital regulator that influences a wide range of tissues through various signaling pathways and when disrupted can lead to significant pathology. ${ }^{2}$ Overexpression of NPP1 is associated with a wide variety of diseases like type 2 diabetes, calcium pyrophosphate dehydrate deposition disease leading to inflammatory arthritis and brain cancers, and thus NPP1 has been proposed as a novel therapeutic protein target, and many NPP1 inhibitors have been developed for this purpose. $^{1-5}$ Recently a new class of imidazopyridineand purine-thioacetamide derivatives has been developed as potent and selective NPP1 inhibitors. ${ }^{1}$ NPP1 has also become a promising target for molecular imaging of NPP1-related diseases and image-guided therapy using positron emission tomography (PET) modality. However, radionuclides including carbon-11 and fluorine-18 labeled NPP1 inhibitors are still not reported. To meet investigator needs within our institution for PET imaging of diabetes, we are interested in tracer development and production. In our previous work, we have redeveloped $\left[{ }^{11} \mathrm{C}\right.$ ]acetate-PET and $\left[{ }^{11} \mathrm{C}\right]$ palmitate-PET to study cardiometabolic response and free fatty acid levels; and carbon-11labeled 4-(phenylamino)-pyrrolo[2,1-f][1,2,4]triazine derivatives for imaging of $\mathrm{p} 38 \alpha$ mitogen-activated protein kinase (MAPK) in diabetes, as indicated in 
Figure $1 .^{6-9}$ In this ongoing study, we first target NPP1 and develop radiolabeled NPP1 inhibitors. Here we report the design, synthesis and labeling of four carbon11-labeled imidazopyridine- and purine-thioacetamide derivatives, $\quad N-\left(3-\left[{ }^{11} \mathrm{C}\right]\right.$ methoxy-4-methoxyphenyl)-2((5-methoxy-3H-imidazo[4,5-b]pyridin-2-

yl)thio)acetamide $\left(3-\left[{ }^{11} \mathrm{C}\right] \mathbf{4 a}\right)$ and $N-\left(4-\left[{ }^{11} \mathrm{C}\right]\right.$ methoxy-3methoxyphenyl)-2-((5-methoxy-3H-imidazo[4,5-

$b]$ pyridin-2-yl)thio)acetamide $\left(4-\left[{ }^{11} \mathrm{C}\right] \mathbf{4 a}\right) ; 2-((6-$ amino9H-purin-8-yl)thio)- $\mathrm{N}-\left(3-\left[{ }^{11} \mathrm{C}\right]\right.$ methoxy-4-

methoxyphenyl)acetamide $\left.\left(3-{ }^{11} \mathrm{C}\right] \mathbf{8 a}\right)$ and 2-((6-amino9H-purin-8-yl)thio)- $N-\left(4-\left[{ }^{11} \mathrm{C}\right]\right.$ methoxy-3-

methoxyphenyl)acetamide $\left(4-\left[{ }^{11} \mathrm{C}\right] \mathbf{8 a}\right)$ as new potential PET agents for imaging of NPP1 in diabetes.

$$
\begin{array}{ll}
\mathrm{CH}_{3}{ }^{11} \mathrm{COOH} & \mathrm{C}_{15} \mathrm{H}_{31}{ }^{11} \mathrm{COOH} \\
{\left[{ }^{11} \mathrm{C}\right] \text { acetate }} & {\left[{ }^{11} \mathrm{C}\right] \text { palmitate }}
\end{array}
$$<smiles>[R]ONC(=O)c1ccc(C)c(Nc2ncnn3cc(C(=O)O[Na])c(C)c23)c1</smiles>

Carbon-11-labeled 4-(phenylamino)-pyrrolo[2,1-f][1,2,3]triazine derivatives, $\mathrm{R}=\mathrm{Me}$; $\mathrm{Et}$

Figure 1. PET tracers for diabetes.

The efforts in developing therapeutic agents for NPP1 enzyme have been accompanied by a growing interest in translating therapeutic agents to diagnostic agents. Two title compounds imidazopyridine-thioacetamide derivative $\mathrm{N}$-(3,4-dimethoxyphenyl)-2-((5-methoxy-3Himidazo[4,5-b]pyridin-2-yl)thio)acetamide (4a), and purine-thioacetamide derivative $2-((6$-amino- $9 H$-purin8 -yl)thio)- $N$-(3,4-dimethoxyphenyl)acetamide (8a) were served as reference standards and selected for radiolabeling. Compounds $\mathbf{4 a}$ and $\mathbf{8 a}$ have been reported previously. ${ }^{1}$ They are potent NPP1 inhibitors with high inhibitory potency, and the $K_{\mathrm{i}}$ values for $\mathbf{4 a}$ and 8a are $29.6 \mathrm{nM}$ and $5.00 \mathrm{nM}$, respectively. ${ }^{1}$ Reference standards $4 \mathbf{a}$ and $8 \mathbf{a}$ and their corresponding precursors $\quad N$-(3-hydroxy-4-methoxyphenyl)-2-((5methoxy-3H-imidazo[4,5- $b]$ pyridin-2-yl)thio)acetamide (4b) and $N$-(4-hydroxy-3-methoxyphenyl)-2-((5methoxy-3H-imidazo[4,5-b]pyridin-2-yl)thio)acetamide (4c), 2-((6-amino-9H-purin-8-yl)thio)- $N$-(3-hydroxy-4methoxyphenyl)acetamide (8b) and 2-((6-amino- $9 H-$ purin-8-yl)thio)- $N$-(4-hydroxy-3methoxyphenyl)acetamide (8c) according to the reported procedures ${ }^{1}$ with modifications.

The imidazopyridine-thioacetamide derivative standard and precursors 4a-c were synthesized as showed in
Scheme 1. The appropriate amino-phenol or dimethoxyaniline reacted with 2-chloroacetyl chloride to obtain compounds 1a-c in $60-80 \%$ yields. Reduction of 6-methoxy-3-nitropyridin-2-amine was achieved catalytically (using $\mathrm{Pd} / \mathrm{C}$ as catalyst under hydrogen gas) to give the compound 6-methoxypyridine-2,3diamine (2). This diamino analogue is instable, compound 2 was immediately used in the next step reaction without further purification. Subsequent imidazole ring compound $\mathbf{3}$ was formed from compound 2 by treating with $\mathrm{CS}_{2}$ and $\mathrm{KOH}$ in $63 \%$ yield. Then substituent alkylation of compound $\mathbf{3}$ with alkyl chloride 1 using $\mathrm{NaOH}$ as base and $\mathrm{EtOH}$ as solvent led to the target compounds $\mathbf{4 a - c}$ in $50-65 \%$ yields.
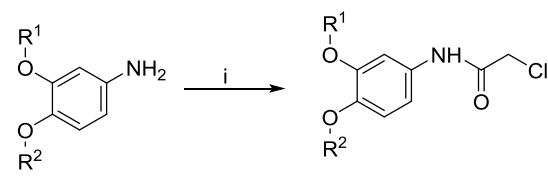

1a: $R^{1}=M e, R^{2}=M e$

1b: $R^{1}=H, R^{2}=M e$

1c: $R^{1}=M e, R^{2}=H$
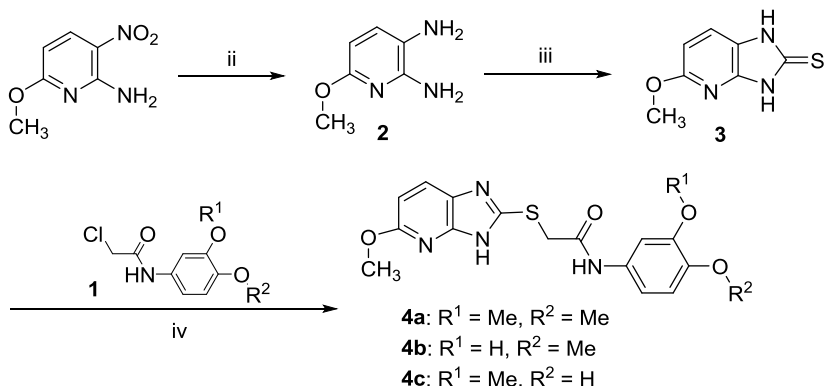

Scheme 1. Synthesis of imidazopyridine-thioacetamide derivative standard and precursors 4a-c. Reagents, conditions and yields: (i) 2chloroacetyl chloride, $\mathrm{Et}_{3} \mathrm{~N}, \mathrm{CH}_{2} \mathrm{Cl}_{2}, \mathrm{RT}$; $60-80 \%$. (ii) $\mathrm{H}_{2}, \mathrm{Pd} / \mathrm{C}, \mathrm{MeOH}$, RT. (iii) $\mathrm{CS}_{2}, \mathrm{KOH}, \mathrm{EtOH}, \mathrm{H}_{2} \mathrm{O}$, reflux; $63 \%$. (iv) $\mathrm{NaOH}, \mathrm{EtOH}, \mathrm{H}_{2} \mathrm{O}$, RT; $50-65 \%$.

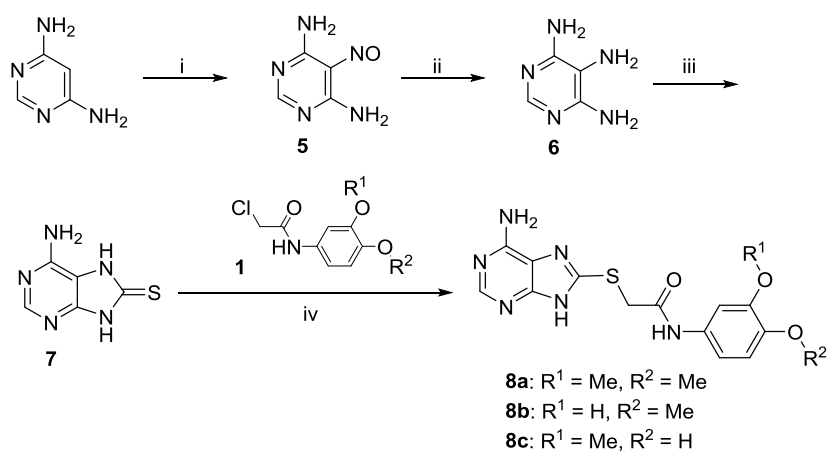

Scheme 2. Synthesis of purine-thioacetamide derivative standard and precursors 8a-c. Reagent, conditions and yield: (i) $\mathrm{NaNO}_{2}, \mathrm{HCl}, 0{ }^{\circ} \mathrm{C}$; 78\%. (ii) $\mathrm{Na}_{2} \mathrm{~S}_{2} \mathrm{O}_{4}, \mathrm{H}_{2} \mathrm{O}, \mathrm{H}_{2} \mathrm{SO}_{4} ; \mathrm{NaOH} ; 41 \%$. (iii) $\mathrm{CS}_{2}, \mathrm{KOH}, \mathrm{EtOH}$, $\mathrm{H}_{2} \mathrm{O}$, reflux; 66\%. (iv) $\mathrm{NaOH}, \mathrm{EtOH}, \mathrm{H}_{2} \mathrm{O}, 60{ }^{\circ} \mathrm{C} ; 45-60 \%$.

The purine-thioacetamide derivative standard and precursors 8a-c were synthesized as depicted in Scheme 2. Commercially available 4,6-pyrimidinediamine was first converted to 5-nitrosopyrimidine-4,6-diamine (5) by $\mathrm{NaNO}_{2}$ and $\mathrm{HCl}$ in $78 \%$ yield. Reduction of 
compound 5 by sodium dithionite $\left(\mathrm{Na}_{2} \mathrm{~S}_{2} \mathrm{O}_{4}\right)$ provided pyrimidine-4,5,6-triamine (6) in $41 \%$ yield. The purine ring formation of compound 6 by treating with $\mathrm{CS}_{2}$ and $\mathrm{KOH}$ in mixed solvents EtOH and $\mathrm{H}_{2} \mathrm{O}$ yielded compound 7 in $66 \%$ yield. Substituent alkylation of the thio moiety of compound 7 with alkyl chloride 1 using $\mathrm{NaOH}$ as base at $60{ }^{\circ} \mathrm{C}$ gave target compound 8a-c in $45-60 \%$ yields.

Synthesis of carbon-11-labeled imidazopyridine- and purine-thioacetamide derivatives $3-\left[{ }^{11} \mathrm{C}\right] \mathbf{4 a}$ and 4$\left[{ }^{11} \mathrm{C}\right] \mathbf{4 a}, 3-\left[{ }^{11} \mathrm{C}\right] \mathbf{8 a}$ and $4-\left[{ }^{11} \mathrm{C}\right] \mathbf{8 a}$ is indicated in Scheme 3. The desmethylated precursors $4 b$ and $4 \mathbf{c}, 8 \mathbf{b}$ and $\mathbf{8 c}$ were labeled by a reactive $\left[{ }^{11} \mathrm{C}\right]$ methylating agent, $\left[{ }^{11} \mathrm{C}\right]$ methyl triflate $\left(\left[{ }^{11} \mathrm{C}\right] \mathrm{CH}_{3} \mathrm{OTf}\right)^{10,11}$ prepared from $\left[{ }^{11} \mathrm{C}_{\mathrm{CO}_{2}}\right.$, through the $O-\left[{ }^{11} \mathrm{C}\right]$ methylation. The labeling reaction was under basic conditions $(2 \mathrm{~N} \mathrm{NaOH})$ in acetonitrile, and the labeling mixture was isolated by a simplified solid-phase extraction (SPE) method ${ }^{12-15}$ to provide target tracers 3-[ $\left.{ }^{11} \mathrm{C}\right] \mathbf{4 a}$ and $4-\left[{ }^{11} \mathrm{C}\right] \mathbf{4 a}$, 3$\left[{ }^{11} \mathrm{C}\right] \mathbf{8 a}$ and $4-\left[{ }^{11} \mathrm{C}\right] \mathbf{8 a}$. The radiochemical yields were $50-60 \%$, decay corrected to end of bombardment (EOB), based on $\left[{ }^{11} \mathrm{C}\right] \mathrm{CO}_{2}$.
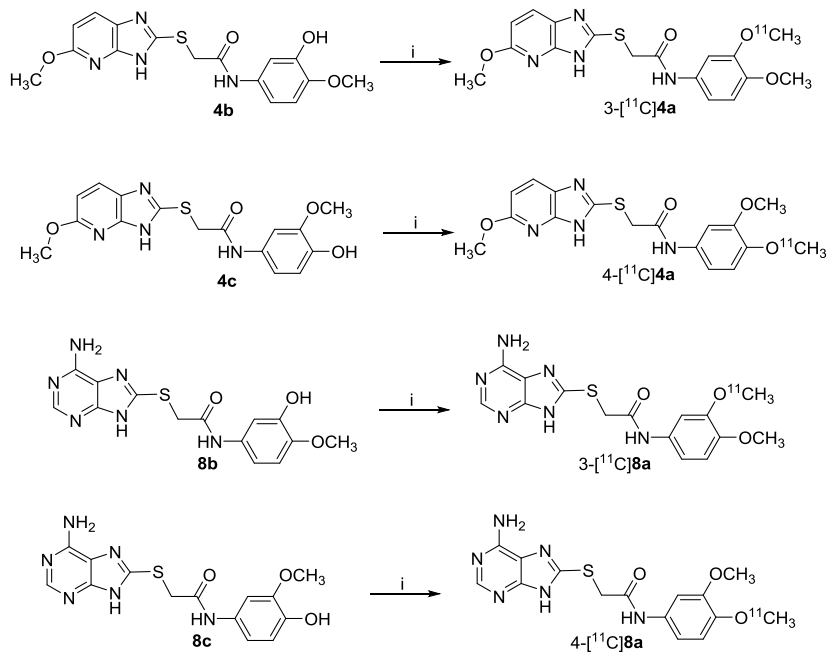

Scheme 3. Synthesis of target tracers 3-[ $\left[{ }^{11} \mathrm{C}\right] \mathbf{4 a}$ and $4-\left[{ }^{11} \mathrm{C}\right] \mathbf{4 a}, 3-\left[{ }^{11} \mathrm{C}\right] \mathbf{8 a}$ and 4- $\left[{ }^{11} \mathrm{C}\right]$ 8a. Reagent, conditions and yield: (i) $\left[{ }^{11} \mathrm{C}\right] \mathrm{CH}_{3} \mathrm{OTf}, \mathrm{CH}_{3} \mathrm{CN}, 2$ $\mathrm{N} \mathrm{NaOH}, 80^{\circ} \mathrm{C}, 3 \mathrm{~min}$; SPE; 50-60\%.

$\left[{ }^{11} \mathrm{C}_{\mathrm{CH}_{3} \mathrm{OTf}}\right.$ is more reactive than commonly used $\left[{ }^{11} \mathrm{C}\right]$ methyl iodide $\left(\left[{ }^{11} \mathrm{C}\right] \mathrm{CH}_{3} \mathrm{I}\right),{ }^{16}$ and thus, the radiochemical yield of $3-\left[{ }^{11} \mathrm{C}\right] \mathbf{4 a}$ and $4-\left[{ }^{11} \mathrm{C}\right] \mathbf{4 a}$, 3$\left[{ }^{11} \mathrm{C}\right] \mathbf{8 a}$ and $4-\left[{ }^{11} \mathrm{C}\right] \mathbf{8 a}$ was relatively high. The large polarity difference between the sodium salt of the phenolic hydroxyl precursor and the corresponding labeled $O$-methylated ether product permitted the use of SPE technique for purification of the labeled product from the radiolabeling reaction mixture. A C-18 Plus Sep-Pak cartridge was used in SPE purification technique. The crude reaction mixture was treated with aqueous $\mathrm{NaHCO}_{3}$ and loaded onto the cartridge by gas pressure. The quenching reagent $0.1 \mathrm{M} \mathrm{NaHCO}_{3}$ combined with an excess of base $2 \mathrm{~N} \mathrm{NaOH}$ used in the reaction effectively deprotonated a phenolic hydroxyl precursor. Any non-reacted precursor was actually converted to the corresponding sodium salt, and any non-reacted $\left[{ }^{11} \mathrm{C}\right] \mathrm{CH}_{3} \mathrm{OTf}$ was actually hydrolyzed to $\left[{ }^{11} \mathrm{C}_{\mathrm{CH}_{3}} \mathrm{OH}\right.$, which would not be trapped to the $\mathrm{C}-18$ Sep-Pak. The cartridge was washed with water to remove radiolabeled by-product $\left[{ }^{11} \mathrm{C}^{-} \mathrm{CH}_{3} \mathrm{OH}\right.$, sodium salt of phenolic hydroxyl precursor and reaction solvent, and total $6 \mathrm{~mL}(2 \times 3 \mathrm{~mL})$ volume of water was enough to wash off all impurities. The final labeled product was eluted with ethanol $(2 \times 2 \mathrm{~mL})$, concentrated by rotary evaporation and reformulated in saline $(10 \mathrm{~mL})$. In our fully automated radiosynthesis module, ${ }^{17-19}$ it is difficult to directly elute the labeled product from a C-18 SepPak to a vial using ethanol $(1 \times 1 \mathrm{~mL}$ or $2 \times 0.5 \mathrm{~mL})$, due to the back pressure in the C-18 Sep-Pak and dead volume in the transfer tubing. The high back pressure is resulted from the eluent (water, ethanol and saline) change. In order to elute most of the labeled product from the C-18 Sep-Pak, we need to increase the volume of the eluent ethanol. For the radiotracer produced for animal study, we used ethanol $(2 \times 2 \mathrm{~mL})$ for elution, and rotary evaporation was required before reformulation. For the radiotracer produced for human study, we used ethanol $(2 \times 1 \mathrm{~mL})$, no evaporation required, and a C-18 Sep-Pak was used for direct reformulation. ${ }^{20-23}$ We have tried to use a C-18 Light Sep-Pak cartridge instead of a C-18 Plus Sep-Pak cartridge to allow smaller volume $(1 \mathrm{~mL})$ of ethanol and to avoid laborious rotary evaporation before formulation. However, there is more serious back pressure in the Light Sep-Pak than in the Plus Sep-Pak, in addition, dead volume in the transfer tubing also affects the elution, and thus it is more difficult to efficiently elute the labeled product from a Light SepPak, which resulted in the low radiochemical yield. The reason is that our home-built fully automated module used many PTFE(polytetrafluoroethylene)/Silicone liners (septa) and Teflon tubing, and these materials cannot afford too high pressure gas $\left(\mathrm{N}_{2}\right)$ push. The pressure of $\mathrm{N}_{2}$ gas introduced in our module is set at $207 \mathrm{kPa}$ (30 Psi). C-18 Light Sep-Pak cartridge works well in manual or semi-automated radiosynthesis in our lab, because we can easily introduce high pressure gas push during the purification and reformulation process. Overall synthesis time was $23 \mathrm{~min}$ from EOB, including approximately $11 \mathrm{~min}$ for $\left[{ }^{11} \mathrm{C}\right] \mathrm{CH}_{3} \mathrm{OTf}$ production, 5 min for $O-\left[{ }^{11} \mathrm{C}\right]$ methylation reaction, and $7 \mathrm{~min}$ for SPE purification, evaporation and reformulation. SPE technique is fast, efficient and convenient and works very well for the $O$-methylated ether tracer purification using the phenolic hydroxyl precursor for radiolabeling. ${ }^{13,24,25}$ 
The radiosynthesis was performed in an automated selfdesigned multi-purpose ${ }^{11} \mathrm{C}$-radiosynthesis module, allowing measurement of specific activity at EOB during synthesis. ${ }^{17-19}$ On line determination of specific activity at EOB is accurate when reverse-phase (RP) high performance liquid chromatography (HPLC) is used as purification method. However, the on-the-fly technique to determine specific activity at EOB is not applied when SPE is used as purification method. The specific activity for the ${ }^{11} \mathrm{C}$-tracers produced in our PET chemistry facility usually ranges from 370 to 1110 $\mathrm{GBq} / \mu \mathrm{mol}$ at EOB according to our previous works. The specific activity of carbon-11-labeled imidazopyridine- and purine-thioacetamide derivatives was estimated in a range of $185-555 \mathrm{GBq} / \mu \mathrm{mol}$ at the end of synthesis (EOS) based on other compounds produced in our facility using the same targetry conditions which have been measured by the on-the-fly technique or the same SPE purification method. ${ }^{26}$ The actual measurement of specific activity at EOS was performed by analytical HPLC ${ }^{27,28}$ and calculated. The exact values of the specific activity for the tracers 3$\left[{ }^{11} \mathrm{C}\right] \mathbf{4 a}$ and $4-\left[{ }^{11} \mathrm{C}\right] \mathbf{4 a}, 3-\left[{ }^{11} \mathrm{C}\right] \mathbf{8 a}$ and $4-\left[{ }^{11} \mathrm{C}\right] \mathbf{8 a}$ were $185-555 \mathrm{GBq} / \mu \mathrm{mol}$ at EOS, which are in agreement with the estimated values and the "on line" determined values. Specific activity of the ${ }^{11} \mathrm{C}$-tracers in the PET chemistry facility are depended on two parts: 1) carrier from the ${ }^{11} \mathrm{C}$-target, and 2) carrier from the ${ }^{11} \mathrm{C}$ radiosynthesis unit. ${ }^{29,30}$ Furthermore, specific activity for the ${ }^{11} \mathrm{C}$-tracers synthesized by ${ }^{11} \mathrm{C}$-methylation with $\left[{ }^{11} \mathrm{C}_{\mathrm{CH}_{3}} \mathrm{OTf}\right.$ in our PET chemistry facility is depended on two parts: 1) carrier from the cyclotron consisted of the ${ }^{11} \mathrm{C}$ gas irradiation target system, and 2) carrier from the $\left[{ }^{11} \mathrm{C}^{11} \mathrm{CH}_{3} \mathrm{OTf}\right.$ system, ${ }^{11} \mathrm{C}$ radiolabeled precursor or called ${ }^{11} \mathrm{C}$ radiolabeled methylating reagent. If we can eliminate ${ }^{12} \mathrm{C}$ carrier-added as much as possible, then we will be able to achieve the highest specific activity. The ${ }^{11} \mathrm{C}$ gas target we used is the Siemens RDS-111 Eclipse cyclotron ${ }^{11} \mathrm{C}$ gas target. The technical trick to produce high specific activity $\left[{ }^{11} \mathrm{C}^{-} \mathrm{CO}_{2}\right.$ is we will usually do 2-3 times pre-burn with the same beam current and short time like $10 \mathrm{~min}$ before production run. This pre-burn will warm up the cyclotron and eliminate significant amount of ${ }^{12} \mathrm{C}$ carrier-added in the cyclotron ${ }^{11} \mathrm{C}$ gas target. We use an Eckert \& Ziegler Modular Lab C-11 Methyl Iodide/Triflate module to produce $\left[{ }^{11} \mathrm{C}\right] \mathrm{CH}_{3} \mathrm{OTf}$, convenient gas phase bromination of $\left[{ }^{11} \mathrm{C}\right]$ methane, and production of $\left[{ }^{11} \mathrm{C}_{\mathrm{CH}_{3} \mathrm{OTf}}\right.$. This 'dry' method, using $\mathrm{Br}_{2}$ to generate a $\left[{ }^{11} \mathrm{C}\right] \mathrm{CH}_{3} \mathrm{Br}$ intermediate, differs from other 'dry' methods using $\mathrm{I}_{2}$ and 'wet' methods using $\mathrm{LiAlH}_{4}$ and $\mathrm{HI}$, and seems to help minimize introduction of additional ${ }^{12} \mathrm{C}$ carrier after $\left[{ }^{11} \mathrm{C}\right] \mathrm{CO}_{2}$ production. ${ }^{11} \mathrm{To}$ further help produce high specific activity $\left[{ }^{11} \mathrm{C}_{\mathrm{CH}_{3} \mathrm{OTf}} \mathrm{O}\right.$, we usually do 2 'test loop' procedures when we set up the module for the actual $\left[{ }^{11} \mathrm{C}^{1} \mathrm{CH}_{3} \mathrm{OTf}\right.$ production run, and 1 actual $\left[{ }^{11} \mathrm{C}\right] \mathrm{CH}_{3} \mathrm{OTf}$ production run before we do $\left[{ }^{11} \mathrm{C}\right]$ methylation labeling reaction. These procedures avoid any leak in the module to introduce additional ${ }^{12} \mathrm{C}$ carrier and eliminate significant amount of original ${ }^{12} \mathrm{C}$ carrier accumulated in the $\left[{ }^{11} \mathrm{C}\right] \mathrm{CH}_{3} \mathrm{OTf}$ production system. Therefore, the specific activity of our ${ }^{11} \mathrm{C}$-tracers is significantly improved.

Chemical purity and radiochemical purity were determined by analytical HPLC. ${ }^{28}$ The chemical purity of the precursors and reference standards was $>93 \%$. The radiochemical purity of the target tracers was $>98 \%$ determined by radio-HPLC through $\gamma$-ray (PIN diode) flow detector, and the chemical purity of the target tracers was $>90 \%$ determined by reversed-phase HPLC through UV flow detector.

The experimental details and characterization data for compounds 1-8 and for the tracers $3-\left[{ }^{11} \mathrm{C}\right] \mathbf{4 a}$ and 4$\left[{ }^{11} \mathrm{C}\right] \mathbf{4 a}, 3-\left[{ }^{11} \mathrm{C}\right] \mathbf{8} \mathbf{a}$ and $4-\left[{ }^{11} \mathrm{C}\right] \mathbf{8 a}$ are given. ${ }^{31}$

In summary, a simple and moderate-to-high-yield synthetic route to synthesize phenolic hydroxyl precursors $\mathbf{4 b - c}$ and $\mathbf{8 b - c}$, ether standards $\mathbf{4 a}$ and $\mathbf{8 a}$, and carbon-11-labeled imidazopyridine- and purinethioacetamide derivatives $3-\left[{ }^{11} \mathrm{C}\right] \mathbf{4 a}$ and $4-\left[{ }^{11} \mathrm{C}\right] \mathbf{4 a}, 3-$ $\left[{ }^{11} \mathrm{C}\right] \mathbf{8 a}$ and $4-\left[{ }^{11} \mathrm{C}\right] \mathbf{8 a}$ has been developed. An automated self-designed multi-purpose $\left[{ }^{11} \mathrm{C}\right]$ radiosynthesis module for the synthesis of $3-\left[{ }^{11} \mathrm{C}\right] \mathbf{4 a}$ and 4- $\left[{ }^{11} \mathrm{C}\right] \mathbf{4 a}, 3-\left[{ }^{11} \mathrm{C}\right] \mathbf{8 a}$ and $4-\left[{ }^{11} \mathrm{C}\right] \mathbf{8 a}$ has been built. The target tracers were easily prepared by $O$ $\left[{ }^{11} \mathrm{C}\right]$ methylation of their corresponding precursors using a reactive $\left[{ }^{11} \mathrm{C}\right]$ methylating agent, $\left[{ }^{11} \mathrm{C}_{\mathrm{CH}_{3}} \mathrm{OTf}\right.$, and isolated by a simplified SPE purification procedure in high radiochemical yields, short overall synthesis time, and high specific radioactivities. These methods are efficient and convenient. It is anticipated that the approaches for the design, synthesis and automation of new tracer, authentic standard and radiolabeling precursor, and improvements to increase radiochemical yield and specific activity of the tracer described here can be applied with advantages to the synthesis of other ${ }^{11} \mathrm{C}$-radiotracers for PET imaging. These chemistry results combined with the reported in vitro biological data ${ }^{1}$ encourage further in vivo biological evaluation of carbon-11-labeled imidazopyridine- and purinethioacetamide derivatives as new candidate PET agents for imaging of NPP1 in diabetes and other heart, cancer and brain diseases.

\section{Acknowledgments}

This work was partially supported by the United States Indiana State Department of Health (ISDH) Indiana Spinal Cord \& Brain Injury Fund (ISDH EDS-A70-2079612). ${ }^{1} \mathrm{H}$ NMR and ${ }^{13} \mathrm{C}$ NMR spectra were recorded 
at 500 and $125 \mathrm{MHz}$, respectively, on a Bruker Avance II $500 \mathrm{MHz}$ NMR spectrometer in the Department of Chemistry and Chemical Biology at Indiana University Purdue University Indianapolis (IUPUI), which is supported by the United States National Science Foundation (NSF) Major Research Instrumentation Program (MRI) grant CHE-0619254.

\section{References and notes}

1. Chang, L.; Lee, S.-Y.; Leonczak, P.; Rozenski, J.; De Jonghe, S.; Hanck, T.; Müller, C. E.; Herdewijn P. J. Med. Chem. 2014, 57, 10080.

2. Lee, S. Y.; Müller, C. E. Electrophoresis 2014, 35, 855.

3. Nadel, Y.; Lecka, J.; Gilad, Y.; Ben-David, G.; Förster, D.; Reiser, G.; Kenigsberg, S.; Camden, J.; Weisman, G. A.; Senderowitz, H.; Sévigny, J.; Fischer, B. J. Med. Chem. 2014, 57, 4677.

4. Lecka, J.; Ben-David, G.; Simhaev, L.; Eliahu, S.; Oscar, J. Jr.; Luyindula, P.; Pelletier, J.; Fischer, B.; Senderowitz, H.; Sévigny, J. J. Med. Chem.. 2013, 56, 8308.

5. Khan, K. M.; Fatima, N.; Rasheed, M.; Jalil, S.; Ambreen, N.; Perveen, S.; Choudhary, M. I. Bioorg. Med. Chem. 2009, 17, 7816.

6. Mock, B. H.; Brown-Proctor, C.; Green, M. A.; Steele, B.; Glick-Wilson, B. E.; Zheng, Q.-H. Nucl. Med. Biol. 2011, 38, 1135.

7. Ng, Y.; Moberly, S. P.; Mather, K. J.; Brown-Proctor, C.; Hutchins, G. D.; Green, M. A. Nucl. Med. Biol. 2013, 40, 361.

8. Moberly, S. P.; Mather, K. J.; Berwick, Z. C.; Owen, M. K.; Goodwill, A. G.; Casalini, E. D.; Hutchins, G. D.; Green, M. A.; Ng, Y.; Considine, R. V.; Perry, K. M.; Chisholm, R. L.; Tune, J. D. Basic Res. Cardiol. 2013, 108, 365.

9. Wang, M.; Gao, M.; Zheng, Q.-H. Bioorg. Med. Chem. Lett. 2014, 24, 3700.

10. Jewett, D. M. Int. J. Radiat. Appl. Instrum. A 1992 , 43, 1383.

11. Mock, B. H.; Mulholland, G. K.; Vavrek, M. T. Nucl. Med. Biol. 1999, 26, 467.

12. Zheng, Q.-H.; Mulholland, G. K. Nucl. Med. Biol. 1996, 23, 981.

13. Gao, M.; Wang, M.; Hutchins, G. D.; Zheng, Q.-H. Appl. Radiat. Isot. 2008, 66, 1891.

14. Gao, M.; Wang, M.; Miller, K. D.; Zheng, Q.-H. Appl. Radiat. Isot. 2012, 70, 1558.

15. Gao, M.; Gao, A. C.; Wang, M.; Zheng, Q.-H. Appl. Radiat. Isot. 2014, 90, 181.

16. Allard, M.; Fouquet, E.; James, D.; Szlosek-Pinaudm, M. Curr. Med. Chem. 2008, 15, 235.

17. Mock, B. H.; Zheng, Q.-H.; DeGrado, T. R. J. Label. Compd. Radiopharm. 2005, 48, S225.

18. Mock, B. H.; Glick-Wilson, B. E.; Zheng, Q.-H.; DeGrado, T. R. J. Label. Compd. Radiopharm. 2005, 48, S224.
19. Wang, M.; Gao, M.; Zheng, Q.-H. Appl. Radiat. Isot. 2012, 70, 965 .

20. Gao, M.; Wang, M.; Zheng, Q.-H. Bioorg. Med. Chem. Lett. 2014, 24, 254.

21. Gao, M.; Wang, M.; Mock, B. H.; Glick-Wilson, B. E.; Yoder, K. K.; Hutchins, G. D.; Zheng, Q.-H. Appl. Radiat. Isot. 2010, 68, 1079.

22. Wang, M.; Gao, M.; Miller, K. D.; Zheng, Q.-H. Steroids 2011, 76, 1331.

23. Wang, M.; Gao, M.; Miller, K. D.; Sledge, G. W.; Zheng, Q.-H. Bioorg. Med. Chem. Lett. 2012, 22, 1569.

24. Gao, M.; Gao, A.; Wang, M.; Zheng, Q.-H. Appl. Radiat. Isot. 2014, 91, 71.

25. Gao, M.; Gao, A.; Wang, M.; Zheng, Q.-H. Bioorg. Med. Chem. Lett. 2014, 24, 5581.

26. Zheng, Q.-H.; Gao, M.; Mock, B. H.; Wang, S.; Hara, T.; Nazih, R.; Miller, M. A.; Receveur, T. J.; Lopshire, J. C.; Groh, W. J.; Zipes, D. P.; Hutchins, G. D.; DeGrado, T. R. Bioorg. Med. Chem. Lett. 2007, 17, 2220.

27. Gao, M.; Yang, Q.; Wang, M.; Miller, K. D.; Sledge, G. W.; Zheng, Q.-H. Appl. Radiat. Isot. 2013, 74, 61.

28. Zheng, Q.-H.; Mock, B. H. Biomed. Chromatogr. 2005, 19, 671 .

29. Gao, M.; Wang, M.; Green, M. A.; Hutchins, G. D.; Zheng, Q.-H. Bioorg. Med. Chem. Lett. 2015, 25, 1965.

30. Wang, M.; Gao, M.; Xu, Z.; Zheng, Q.-H. Bioorg. Med. Chem. Lett. 2015, 25, 4587.

31. (a) General: All commercial reagents and solvents were purchased from Sigma-Aldrich and Fisher Scientific, and used without further purification.

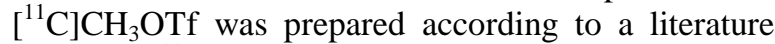
procedure. ${ }^{11}$ Melting points were determined on a MEL-TEMP II capillary tube apparatus and were uncorrected. ${ }^{1} \mathrm{H}$ NMR and ${ }^{13} \mathrm{C}$ NMR spectra were recorded at 500 and $125 \mathrm{MHz}$, respectively, on a Bruker Avance II $500 \mathrm{MHz}$ NMR spectrometer using tetramethylsilane (TMS) as an internal standard. Chemical shift data for the proton resonances were reported in parts per million (ppm, $\delta$ scale) relative to internal standard TMS $(\delta 0.0)$, and coupling constants $(J)$ were reported in hertz $(\mathrm{Hz})$. Liquid chromatography-mass spectra (LC-MS) analysis was performed on an Agilent system, consisting of an 1100 series HPLC connected to a diode array detector and a 1946D mass spectrometer configured for positiveion/negative-ion electrospray ionization. The high resolution mass spectra (HRMS) were obtained using a Waters/Micromass LCT Classic spectrometer. Chromatographic solvent proportions are indicated as volume: volume ratio. Thin-layer chromatography (TLC) was run using Analtech silica gel GF uniplates $\left(5 \times 10 \mathrm{~cm}^{2}\right)$. Plates were visualized under UV light. Normal phase flash column chromatography was carried out on EM Science silica gel 60 (230-400 mesh) with a forced flow of the indicated solvent system in the proportions described below. All 
moisture- and air-sensitive reactions were performed under a positive pressure of nitrogen maintained by a direct line from a nitrogen source. Analytical RP HPLC was performed using a Prodigy (Phenomenex) $5 \mu \mathrm{m}$ C-18 column, $4.6 \times 250 \mathrm{~mm}$; mobile phase $40 \%$ $\mathrm{CH}_{3} \mathrm{CN} / 60 \% \mathrm{H}_{2} \mathrm{O}$; flow rate $1.5 \mathrm{~mL} / \mathrm{min}$; and $\mathrm{UV}$ $(254 \mathrm{~nm})$ and $\gamma$-ray (PIN diode) flow detectors. C18 Plus Sep-Pak cartridges were obtained from Waters Corporation (Milford, MA). Sterile Millex-GS 0.22 $\mu \mathrm{m}$ filter units were obtained from Millipore Corporation (Bedford, MA).

(b) 2-Chloro-N-(3,4-dimethoxyphenyl)acetamide (1a): To a solution of 3,4-dimethoxyaniline $(3.0 \mathrm{~g}, 19.58$ $\mathrm{mmol})$ in $\mathrm{CH}_{2} \mathrm{Cl}_{2}(50 \mathrm{~mL})$ was added $\mathrm{Et}_{3} \mathrm{~N}(2.97 \mathrm{~g}$, $29.37 \mathrm{mmol}$ ), the mixture was cooled to $0{ }^{\circ} \mathrm{C}$ on an ice bath, and 2-chloroacetyl chloride (2.76 g, $24.48 \mathrm{mmol})$ was added dropwise. The reaction mixture was allowed to warm to room temperature (RT) and stirred overnight. Then the mixture was evaporated under reduced pressure, and the crude product was washed with ice-cold water. The precipitate was filtered off, washed with water and dried, affording a gray solid 1a (4.5 g, 80\%). $R_{f}=0.82\left(1: 19 \mathrm{MeOH} / \mathrm{CH}_{2} \mathrm{Cl}_{2}\right)$, mp 99$101{ }^{\circ} \mathrm{C} .{ }^{1} \mathrm{H}$ NMR $\left(\mathrm{CDCl}_{3}\right): \delta 3.87\left(\mathrm{~s}, 3 \mathrm{H}, \mathrm{OCH}_{3}\right), 3.89$ (s, $\left.3 \mathrm{H}, \mathrm{OCH}_{3}\right), 4.18\left(\mathrm{~s}, 2 \mathrm{H}, \mathrm{CH}_{2}\right), 6.82(\mathrm{~d}, J=8.5 \mathrm{~Hz}$, $1 \mathrm{H}, \mathrm{Ph}-\mathrm{H}), 6.94$ (dd, $J=2.0,8.5 \mathrm{~Hz}, 1 \mathrm{H}, \mathrm{Ph}-\mathrm{H}), 7.27$ $(\mathrm{d}, J=2.0 \mathrm{~Hz}, 1 \mathrm{H}, \mathrm{Ph}-\mathrm{H}), 8.15(\mathrm{~s}, 1 \mathrm{H}, \mathrm{NH}) . \mathrm{MS}$ (ESI): $230\left([\mathrm{M}+\mathrm{H}]^{+}, 100 \%\right)$.

(c)

2-Chloro-N-(3-hydroxy-4dimethoxyphenyl)acetamide ( $\mathbf{l b})$ : To a solution of solution of 5-amino-2-methoxyphenol $(2.78 \mathrm{~g}, 20$ mmol) in $\mathrm{CH}_{2} \mathrm{Cl}_{2}(50 \mathrm{~mL})$ was added $\mathrm{Et}_{3} \mathrm{~N}(3.03 \mathrm{~g}, 30$ mmol), the mixture was cooled to $0{ }^{\circ} \mathrm{C}$, and 2 chloroacetyl chloride $(2.37 \mathrm{~g}, 21 \mathrm{mmol})$ was added dropwise. The reaction mixture was allowed to warm to RT and stirred overnight. After the reaction completed, the solvents were removed, and the residue was purified by column chromatography on silica gel with eluent (0:100 to $\left.1: 99 \mathrm{MeOH} / \mathrm{CH}_{2} \mathrm{Cl}_{2}\right)$ to give a black solid product $1 \mathrm{~b}(2.58 \mathrm{~g}, 60 \%) . R_{f}=0.69(1: 19$ $\mathrm{MeOH} / \mathrm{CH}_{2} \mathrm{Cl}_{2}$ ), mp 122-124 ${ }^{\circ} \mathrm{C}$. ${ }^{1} \mathrm{H}$ NMR (DMSO$\left.\mathrm{d}_{6}\right): \delta 3.72\left(\mathrm{~s}, 3 \mathrm{H}, \mathrm{OCH}_{3}\right), 4.18\left(\mathrm{~s}, 2 \mathrm{H}, \mathrm{CH}_{2}\right), 6.83(\mathrm{~d}, J$ $=8.5 \mathrm{~Hz}, 1 \mathrm{H}, \mathrm{Ph}-\mathrm{H}), 6.93(\mathrm{dd}, J=2.0,8.5 \mathrm{~Hz}, 1 \mathrm{H}$, $\mathrm{Ph}-\mathrm{H}), 7.15(\mathrm{~d}, J=2.0 \mathrm{~Hz}, 1 \mathrm{H}, \mathrm{Ph}-\mathrm{H}), 9.08(\mathrm{~s}, 1 \mathrm{H}$, $\mathrm{NH}), 10.02(\mathrm{~s}, 1 \mathrm{H}, \mathrm{OH}) . \mathrm{MS}(\mathrm{ESI}): 216\left([\mathrm{M}+\mathrm{H}]^{+}\right.$, 100\%); MS (ESI): 214 ([M-H] $\left.]^{-}, 20 \%\right)$.

(d) 2-Chloro- $N$-(4-hydroxy-3methoxyphenyl)acetamide (1c): Compound 1c was prepared from 4-amino-2-methoxyphenol and 2chloroacetyl chloride according to the procedure for the synthesis of $\mathbf{1 b}$, as a brown solid, yield $62 \%$. $R_{f}=$ 0.65 (1:19 $\left.\mathrm{MeOH} / \mathrm{CH}_{2} \mathrm{Cl}_{2}\right), \mathrm{mp} 126-128{ }^{\circ} \mathrm{C} .{ }^{1} \mathrm{H} \mathrm{NMR}$ (DMSO-d $\left.\mathrm{d}_{6}\right): \delta 3.71\left(\mathrm{~s}, 3 \mathrm{H}, \mathrm{OCH}_{3}\right), 4.19\left(\mathrm{~s}, 2 \mathrm{H}, \mathrm{CH}_{2}\right)$, $6.70(\mathrm{~d}, J=8.5 \mathrm{~Hz}, 1 \mathrm{H}, \mathrm{Ph}-\mathrm{H}), 6.94$ (dd, $J=2.5,8.5$ $\mathrm{Hz}, 1 \mathrm{H}, \mathrm{Ph}-\mathrm{H}), 7.24$ (d, $J=2.0 \mathrm{~Hz}, 1 \mathrm{H}, \mathrm{Ph}-\mathrm{H}), 8.79$ (s, $1 \mathrm{H}, \mathrm{NH}), 10.06(\mathrm{~s}, 1 \mathrm{H}, \mathrm{OH})$. MS (ESI): $216\left([\mathrm{M}+\mathrm{H}]^{+}\right.$, 70\%); MS (ESI): 214 ([M-H]', 100\%).

(e) 6-Methoxypyridine-2,3-diamine (2): To a solution of 6-methoxy-3-nitropyridin-2-amine (25 g, 0.148 mol) in methanol was added palladium on carbon $(10 \% \mathrm{Pd} / \mathrm{C}, 0.70 \mathrm{~g})$. The reaction mixture was stirred at RT for $15 \mathrm{~h}$ under an atmosphere of hydrogen gas (55 psi). The mixture was filtered over Celite, and the filtrate was collected. The solvent was evaporated to afford a black solid crude product 2 (20.4 g). Because of the instability of the diamino analogue, the product was immediately used in next step reaction without further purification. $R_{f}=0.40\left(1: 19 \mathrm{MeOH} / \mathrm{CH}_{2} \mathrm{Cl}_{2}\right)$. MS (ESI): $140\left([\mathrm{M}+\mathrm{H}]^{+}, 100 \%\right)$.

(f) 5-Methoxy-1,3-dihydro-2H-imidazo[4,5b]pyridine-2-thione (3): To a solution of compound 2 $(20.56 \mathrm{~g}, 148 \mathrm{mmol})$ in a mixture of EtOH $(200 \mathrm{~mL})$ and water $(40 \mathrm{~mL})$ was added $\mathrm{KOH}(9.75 \mathrm{~g}, 148$ $\mathrm{mmol})$ and $\mathrm{CS}_{2}(22.5 \mathrm{~g}, 296 \mathrm{mmol})$. The reaction mixture was stirred at reflux for $12 \mathrm{~h}$. The solvents were evaporated, and the residue was purified by column chromatography on silica gel with eluent (2:98 to $10: 90 \mathrm{MeOH} / \mathrm{CH}_{2} \mathrm{Cl}_{2}$ ), affording a gray solid product $3(16.9 \mathrm{~g}, \quad 63 \%) . \quad R_{f}=0.50 \quad(1: 19$ $\mathrm{MeOH} / \mathrm{CH}_{2} \mathrm{Cl}_{2}$ ), mp 246-248 ${ }^{\circ} \mathrm{C}$. ${ }^{\mathrm{H}}$ NMR (DMSO$\left.\mathrm{d}_{6}\right): \delta 3.83\left(\mathrm{~s}, 3 \mathrm{H}, \mathrm{OCH}_{3}\right), 6.56(\mathrm{~d}, J=8.5 \mathrm{~Hz}, 1 \mathrm{H}, \mathrm{Ar}-$ $\mathrm{H}), 7.44(\mathrm{~d}, J=8.5 \mathrm{~Hz}, 1 \mathrm{H}, \mathrm{Ar}-\mathrm{H}), 12.73(\mathrm{~s}, 2 \mathrm{H}, \mathrm{NH})$. MS (ESI): $182\left([\mathrm{M}+\mathrm{H}]^{+}, 100 \%\right)$; MS (ESI): 180 ([M$\left.\mathrm{H}^{-}, 23 \%\right)$.

(g) General procedure to prepare compounds 4a-c: To a solution of compound $3(360 \mathrm{mg}, 2.0 \mathrm{mmol})$ in a mixture of EtOH $(60 \mathrm{~mL})$ and $1 \mathrm{~N}$ aq. $\mathrm{NaOH}(2.2 \mathrm{~mL}$, $2.2 \mathrm{mmol})$, compound 1 ( $2.1 \mathrm{mmol})$ was added. The resulting reaction mixture was stirred overnight at RT. Then solvents were removed under reduced pressure, and the crude product was purified by column chromatography on silica gel with eluent $(0: 100$ to 3:97 $\mathrm{MeOH} / \mathrm{CH}_{2} \mathrm{Cl}_{2}$ ) to give a white solid product 4 (50-65\% yields).

$\mathrm{N}$-(3,4-Dimethoxyphenyl)-2-((5-methoxy-3H-

imidazo[4,5-b]pyridin-2-yl)thio)acetamide (4a): $R_{f}=$ $0.61\left(1: 19 \mathrm{MeOH} / \mathrm{CH}_{2} \mathrm{Cl}_{2}\right), \mathrm{mp} 175-177{ }^{\circ} \mathrm{C} .{ }^{1} \mathrm{H}$ NMR $\left(\right.$ DMSO-d $\left._{6}\right): \delta 3.66\left(\mathrm{~s}, 6 \mathrm{H}, 2 \times \mathrm{OCH}_{3}\right), 3.84(\mathrm{~s}, 3 \mathrm{H}$, $\left.\mathrm{OCH}_{3}\right), 4.20\left(\mathrm{~s}, 2 \mathrm{H}, \mathrm{CH}_{2}\right), 6.59(\mathrm{~d}, J=8.5 \mathrm{~Hz}, 1 \mathrm{H}, \mathrm{Ar}-$ $\mathrm{H}), 6.88(\mathrm{~d}, J=8.5 \mathrm{~Hz}, 1 \mathrm{H}, \mathrm{Ar}-\mathrm{H}), 7.07(\mathrm{~d}, J=8.0 \mathrm{~Hz}$, $1 \mathrm{H}, \mathrm{Ar}-\mathrm{H}), 7.28(\mathrm{~d}, J=2.5 \mathrm{~Hz}, 1 \mathrm{H}, \mathrm{Ar}-\mathrm{H}), 7.80(\mathrm{~d}, J=$ $8.5 \mathrm{~Hz}, 1 \mathrm{H}, \mathrm{Ar}-\mathrm{H}$ ), 10.30 (br s, 1H, NH), 12.76 and $13.10(2 \mathrm{~s}, 1 \mathrm{H}, \mathrm{NH}) . \mathrm{MS}(\mathrm{ESI}): 375\left([\mathrm{M}+\mathrm{H}]^{+}, 100 \%\right)$; MS (ESI): 373 ([M-H] $\left.]^{-}, 20 \%\right)$.

$\mathrm{N}$-(3-Hydroxy-4-methoxyphenyl)-2-((5-methoxy-3Himidazo[4,5-b]pyridin-2-yl)thio)acetamide $(\mathbf{4 b}): R_{f}=$ $0.35\left(1: 19 \mathrm{MeOH} / \mathrm{CH}_{2} \mathrm{Cl}_{2}\right), \mathrm{mp} 216-218{ }^{\circ} \mathrm{C} .{ }^{1} \mathrm{H} \mathrm{NMR}$ $\left(\mathrm{DMSO}_{\mathrm{d}}\right): \delta 3.71\left(\mathrm{~s}, 3 \mathrm{H}, \mathrm{OCH}_{3}\right), 3.85\left(\mathrm{~s}, 3 \mathrm{H}, \mathrm{OCH}_{3}\right)$, $4.19\left(\mathrm{~s}, 2 \mathrm{H}, \mathrm{CH}_{2}\right), 6.59$ (d, $\left.J=8.5 \mathrm{~Hz}, 1 \mathrm{H}, \mathrm{Ar}-\mathrm{H}\right), 6.82$ $(\mathrm{d}, J=8.5 \mathrm{~Hz}, 1 \mathrm{H}$, Ar-H), $6.92(\mathrm{dd}, J=2.0,8.5 \mathrm{~Hz}$, $1 \mathrm{H}, \mathrm{Ar}-\mathrm{H}), 7.14(\mathrm{~d}, J=2.5 \mathrm{~Hz}, 1 \mathrm{H}, \mathrm{Ar}-\mathrm{H}), 7.73$ and $7.80(2 \mathrm{~s}, 1 \mathrm{H}, \mathrm{Ar}-\mathrm{H}), 9.06$ (s, 1H, OH), 10.17 (br s, 1H, $\mathrm{NH}), 12.74$ and $13.09(2 \mathrm{~s}, 1 \mathrm{H}, \mathrm{NH}) .{ }^{13} \mathrm{C} \mathrm{NMR}$ $\left(\right.$ DMSO-d $\left._{6}\right): \delta 35.99,53.34,55.88,104.56,107.62$, $109.83,112.54,121.00,128.20,130.10,132.50$, 143.97, 146.48, 148.00, 159.96, 165.37. MS (ESI): $361\left([\mathrm{M}+\mathrm{H}]^{+}, 100 \%\right)$; MS (ESI): $359([\mathrm{M}-\mathrm{H}]-25 \%)$. 
HRMS (ESI): calcd for $\mathrm{C}_{16} \mathrm{H}_{17} \mathrm{~N}_{4} \mathrm{O}_{4} \mathrm{~S} \quad\left([\mathrm{M}+\mathrm{H}]^{+}\right)$ 361.0971, found 361.0954.

$\mathrm{N}$-(4-Hydroxy-3-methoxyphenyl)-2-((5-methoxy-3Himidazo[4,5-b]pyridin-2-yl)thio)acetamide (4c): $R_{f}=$ $0.33\left(1: 19 \mathrm{MeOH} / \mathrm{CH}_{2} \mathrm{Cl}_{2}\right)$, mp 119-121 ${ }^{\circ} \mathrm{C} .{ }^{1} \mathrm{H}$ NMR $\left(\right.$ DMSO-d $\left._{6}\right): \delta 3.72\left(\mathrm{~s}, 3 \mathrm{H}, \mathrm{OCH}_{3}\right), 3.84$ and $3.85(2 \mathrm{~s}$, $\left.3 \mathrm{H}, \mathrm{OCH}_{3}\right), 4.18$ and $4.21\left(2 \mathrm{~s}, 2 \mathrm{H}, \mathrm{CH}_{2}\right), 6.60(\mathrm{t}, J=$ $8.5 \mathrm{~Hz}, 1 \mathrm{H}, \mathrm{Ar}-\mathrm{H}), 6.68(\mathrm{~d}, J=8.5 \mathrm{~Hz}, 1 \mathrm{H}, \mathrm{Ar}-\mathrm{H})$, 6.91 and $6.94(2 \mathrm{~d}, J=8.5,1 \mathrm{H}, \mathrm{Ar}-\mathrm{H}), 7.26(\mathrm{~s}, 1 \mathrm{H}, \mathrm{Ar}-$ $\mathrm{H}), 7.71$ and $7.81(2 \mathrm{~d}, J=8.5 \mathrm{~Hz}, 1 \mathrm{H}, \mathrm{Ar}-\mathrm{H}), 8.77(\mathrm{~s}$, $1 \mathrm{H}, \mathrm{OH}), 10.18$ and 10.24 (2br s, 1H, NH), 12.74 and $13.10(2 \mathrm{~s}, 1 \mathrm{H}, \mathrm{NH}) .{ }^{13} \mathrm{C}$ NMR (DMSO-d 6 ): $\delta 35.91$, 53.37, 55.47, 104.04, 104.69, 115.24, 121.30, 122.05, $128.04,130.22,131.00,142.70,147.24,147.92$, 159.94, 165.29. MS (ESI): 361 $\left([\mathrm{M}+\mathrm{H}]^{+}, 100 \%\right)$; MS (ESI): 359 ([M-H], $30 \%)$. HRMS (ESI): calcd for $\mathrm{C}_{16} \mathrm{H}_{17} \mathrm{~N}_{4} \mathrm{O}_{4} \mathrm{~S}\left([\mathrm{M}+\mathrm{H}]^{+}\right)$361.0971, found 361.0955.

(h) 5-Nitrosopyrimidine-4,6-diamine (5): A solution of 4,6-pyrimidinediamine $(16.0 \mathrm{~g}, 110 \mathrm{mmol})$ in $3 \mathrm{~N}$ $\mathrm{HCl}(367 \mathrm{~mL})$ was cooled in an ice bath, and then $\mathrm{NaNO}_{2}(8.73 \mathrm{~g}, 126 \mathrm{mmol})$ in $\mathrm{H}_{2} \mathrm{O}(30 \mathrm{~mL})$ was added dropwise. The mixture was stirred for $30 \mathrm{~min}$ at $0{ }^{\circ} \mathrm{C}$, and then $2 \mathrm{~h}$ at RT. The violet solution was neutralized with $\mathrm{NaHCO}_{3}$ to $\mathrm{pH}$ 8, the resulting precipitate collected, suspended in $\mathrm{H}_{2} \mathrm{O}$ and head to $70{ }^{\circ} \mathrm{C}$, filtered, washed with $\mathrm{MeOH}$, and dried to give a blue solid product 5 (14.5 g, 78\%). $R_{f}=0.81(1: 5$ $\mathrm{MeOH} / \mathrm{CH}_{2} \mathrm{Cl}_{2}$ ), mp > $350{ }^{\circ} \mathrm{C} .{ }^{1} \mathrm{H}$ NMR $\left(\right.$ DMSO-d $\left._{6}\right)$ : $\delta 7.93(\mathrm{~s}, 1 \mathrm{H}, \mathrm{Ar}-\mathrm{H}), 8.04(\mathrm{~s}, 1 \mathrm{H}, \mathrm{N} H \mathrm{H}), 8.44(\mathrm{~s}, 1 \mathrm{H}$, $\mathrm{NH} H), 9.11$ (s, NHH), 10.05 (s, 1H, NHH). MS (ESI): $140\left([\mathrm{M}+\mathrm{H}]^{+}, 100 \%\right)$.

(i) Pyrimidine-4,5,6-triamine (6): Compound 5 (10.0 $\mathrm{g}, 72 \mathrm{mmol})$ was dissolved in water $(110 \mathrm{~mL})$ and treated with sodium dithionite $(27.6 \mathrm{~g}, 158 \mathrm{mmol})$, which was added in portions at RT. The resulting yellow mixture was then treated with $50 \%$ aq. $\mathrm{H}_{2} \mathrm{SO}_{4}$ (141 g, $720 \mathrm{mmol}$ ) and heated to $80{ }^{\circ} \mathrm{C}$ for $5 \mathrm{~min}$, and then cooled to $10{ }^{\circ} \mathrm{C}$ in an ice bath. The resulting precipitate was filtered off and washed with aq. ethanol and dried to afford a yellowish solid intermediate 4,5,6-triaminopyrimidine sulfate $(8.81 \mathrm{~g})$. A mixture of 4,5,6-triaminopyrimidine sulfate $(8.81 \mathrm{~g}$, $39.5 \mathrm{mmol}), \mathrm{NaOH}(3.48 \mathrm{~g}, 87 \mathrm{mmol})$ and water $(80$ $\mathrm{mL}$ ) was heated to $80{ }^{\circ} \mathrm{C}$ until all the solid was dissolved. The solution was cooled to $0{ }^{\circ} \mathrm{C}$ and $\mathrm{pH}$ was adjusted to 7.0 with $1 \mathrm{~N} \mathrm{HCl}$, whereupon the free base precipitated as an off-white solid product 6 (3.69 g, $41 \%$ from 5). $R_{f}=0.26\left(1: 5 \mathrm{MeOH} / \mathrm{CH}_{2} \mathrm{Cl}_{2}\right), \mathrm{mp}$ 288-290 ${ }^{\circ} \mathrm{C} .{ }^{1} \mathrm{H}$ NMR (DMSO-d ${ }_{6}$ ): $\delta 4.33$ (br s, $2 \mathrm{H}$, $\left.\mathrm{NH}_{2}\right), 6.45$ (br s, $\left.4 \mathrm{H}, 2 \times \mathrm{NH}_{2}\right), 7.68(\mathrm{~s}, 1 \mathrm{H}, \mathrm{Ar}-\mathrm{H})$. MS (ESI): $126\left([\mathrm{M}+\mathrm{H}]^{+}, 100 \%\right)$.

(j) 6-Amino-7,9-dihydro-8H-purine-8-thione (7): To a mixture of compound $6(4.13 \mathrm{~g}, 33 \mathrm{mmol})$ in solvents of EtOH $(200 \mathrm{~mL})$ and water $(10 \mathrm{~mL})$ was added $\mathrm{KOH}(2.28 \mathrm{~g}, 35 \mathrm{mmol})$ and $\mathrm{CS}_{2}(3.33 \mathrm{~g}, 43.8 \mathrm{mmol})$. The reaction mixture was stirred at reflux for overnight. The solvents were evaporated, and the residue were rinsed with water and acetone to obtain a yellow product 7 (3.64 g, 66\%). $R_{f}=0.24(1: 9$
$\mathrm{MeOH} / \mathrm{CH}_{2} \mathrm{Cl}_{2}$ ), mp $>350{ }^{\circ} \mathrm{C} .{ }^{1} \mathrm{H}$ NMR $\left(\right.$ DMSO-d $\mathrm{d}_{6}$ ): $\delta 6.59\left(\mathrm{~s}, 2 \mathrm{H}, \mathrm{NH}_{2}\right), 7.98(\mathrm{~s}, 1 \mathrm{H}, \mathrm{Ar}-\mathrm{H}), 12.20(\mathrm{br} \mathrm{s}$, $2 \mathrm{H}, 2 \times \mathrm{NH}) . \mathrm{MS}(\mathrm{ESI}): 168\left([\mathrm{M}+\mathrm{H}]^{+}, 90 \%\right) ; \mathrm{MS}$ (ESI): 166 ([M-H]', 100\%).

(k) General procedure to prepare compounds $8 \boldsymbol{a}-\boldsymbol{c}$ : To a solution of compound 7 (334 mg, $2.0 \mathrm{mmol})$ in a mixture of EtOH $(100 \mathrm{~mL})$ and $1 \mathrm{~N}$ aq. $\mathrm{NaOH}(2.6$ $\mathrm{mL}, 2.6 \mathrm{mmol})$, compound $1(2.0 \mathrm{mmol})$ was added. The resulting reaction mixture was stirred overnight at $60{ }^{\circ} \mathrm{C}$. Then solvents were removed under reduced pressure, and the crude product was purified by column chromatography on silica gel with eluent (2:98 to $10: 90 \mathrm{MeOH} / \mathrm{CH}_{2} \mathrm{Cl}_{2}$ ) to give a gray solid product 8 (45-60\% yields).

2-((6-Amino-9H-purin-8-yl)thio)- $\mathrm{N}-(3,4-$

dimethoxyphenyl)acetamide $\quad(\mathbf{8 a}): \quad R_{f}=0.26 \quad(1: 9$ $\mathrm{MeOH} / \mathrm{CH}_{2} \mathrm{Cl}_{2}$ ), mp 270-272 ${ }^{\circ} \mathrm{C}$. ${ }^{1} \mathrm{H}$ NMR (DMSO$\left.\mathrm{d}_{6}\right): \delta 3.70\left(\mathrm{~s}, 6 \mathrm{H}, 2 \times \mathrm{OCH}_{3}\right), 4.12\left(\mathrm{~s}, 2 \mathrm{H}, \mathrm{CH}_{2}\right), 6.87$ $(\mathrm{d}, J=8.5 \mathrm{~Hz}, 1 \mathrm{H}, \mathrm{Ar}-\mathrm{H}), 7.08-7.10(\mathrm{~m}, 3 \mathrm{H}, \mathrm{Ar}-\mathrm{H}$ and $\left.\mathrm{NH}_{2}\right), 7.25(\mathrm{~d}, J=2.5 \mathrm{~Hz}, 1 \mathrm{H}, \mathrm{Ar}-\mathrm{H}), 8.05$ (s, $1 \mathrm{H}, \mathrm{Ar}-$ $\mathrm{H}), 10.18$ (s, 1H, NH), 13.14 (s, 1H, NH). MS (ESI): 361 ([M+H $\left.]^{+}, 100 \%\right)$; MS (ESI): 359 ([M-H] $\left.]^{-}, 30 \%\right)$.

2-((6-Amino-9H-purin-8-yl)thio)- $N$-(3-hydroxy-4-

methoxyphenyl)acetamide $(\boldsymbol{8 b}): R_{f}=0.29 \quad(1: 7$ $\mathrm{MeOH} / \mathrm{CH}_{2} \mathrm{Cl}_{2}$ ), mp 261-263 ${ }^{\circ} \mathrm{C}$. ${ }^{1} \mathrm{H}$ NMR (DMSO$\left.\mathrm{d}_{6}\right): \delta 3.70\left(\mathrm{~s}, 3 \mathrm{H}, \mathrm{OCH}_{3}\right), 4.12\left(\mathrm{~s}, 2 \mathrm{H}, \mathrm{CH}_{2}\right), 6.81(\mathrm{~d}, \mathrm{~J}$ $=8.5 \mathrm{~Hz}, 1 \mathrm{H}, \mathrm{Ar}-\mathrm{H}), 6.90(\mathrm{dd}, J=2.5,8.5 \mathrm{~Hz}, 1 \mathrm{H}$, Ar-H), $7.05\left(\right.$ br s, $\left.2 \mathrm{H}, \mathrm{NH}_{2}\right) 7.14(\mathrm{~d}, J=2.5 \mathrm{~Hz}, 1 \mathrm{H}$, Ar-H), 8.05 (s, 1H, Ar-H), 9.05 (s, 1H, OH), 10.57 (s, 1H, NH), 13.09 (s, 1H, NH). MS (ESI): $347\left([\mathrm{M}+\mathrm{H}]^{+}\right.$, 100\%); MS (ESI): 345 ([M-H]', 70\%). HRMS (ESI): calcd for $\mathrm{C}_{14} \mathrm{H}_{15} \mathrm{~N}_{6} \mathrm{O}_{3} \mathrm{~S}\left([\mathrm{M}+\mathrm{H}]^{+}\right)$347.0926, found 347.0912 .

2-((6-Amino-9H-purin-8-yl)thio)-N-(4-hydroxy-3-

methoxyphenyl)acetamide $(8 \mathrm{c}): \quad R_{f}=0.37 \quad(1: 7$ $\mathrm{MeOH} / \mathrm{CH}_{2} \mathrm{Cl}_{2}$ ), mp 266-268 ${ }^{\circ} \mathrm{C}$. ${ }^{1} \mathrm{H}$ NMR (DMSO$\left.\mathrm{d}_{6}\right): \delta 3.71\left(\mathrm{~s}, 6 \mathrm{H}, 2 \times \mathrm{OCH}_{3}\right), 4.11\left(\mathrm{~s}, 2 \mathrm{H}, \mathrm{CH}_{2}\right), 6.65$ (d, J = 8.5 Hz, 1H, Ar-H), 6.93 (dd, $J=2.0,8.5 \mathrm{~Hz}$, $1 \mathrm{H}, \mathrm{Ar}-\mathrm{H}), 7.09$ (br s, $\left.2 \mathrm{H}, \mathrm{NH}_{2}\right), 7.23(\mathrm{~d}, J=2.0 \mathrm{~Hz}$, $1 \mathrm{H}, \operatorname{Ar}-\mathrm{H}), 8.05(\mathrm{~s}, 1 \mathrm{H}, \operatorname{Ar}-\mathrm{H}), 8.77(\mathrm{~s}, 1 \mathrm{H}, \mathrm{OH})$, $10.09(\mathrm{~s}, 1 \mathrm{H}, \mathrm{NH}), 13.11(\mathrm{~s}, 1 \mathrm{H}, \mathrm{NH}) .{ }^{13} \mathrm{C} \mathrm{NMR}$ $\left(\right.$ DMSO-d $\left._{6}\right): \delta 35.89,55.48,103.50,104.72,106.40$, $108.10,111.79,115.19,119.20,130.89,142.73$, $142.90, \quad 147.23, \quad 151.57, \quad 165.44 . \quad M S \quad(E S I):$ $347\left([\mathrm{M}+\mathrm{H}]^{+}, 80 \%\right)$; MS (ESI): $345\left([\mathrm{M}-\mathrm{H}]^{-}, 100 \%\right)$. HRMS (ESI): calcd for $\mathrm{C}_{14} \mathrm{H}_{15} \mathrm{~N}_{6} \mathrm{O}_{3} \mathrm{~S}\left([\mathrm{M}+\mathrm{H}]^{+}\right)$ 347.0926, found 347.0914.

(l) General procedure to prepare target tracers $N-(3-$ $\left[{ }^{11}\right.$ C]methoxy-4-methoxyphenyl)-2-((5-methoxy-3H-

imidazo[4,5-b]pyridin-2-yl)thio)acetamide $\left(3-\left[{ }^{11} \mathrm{C}\right] 4 \mathrm{a}\right)$ and $\left.\quad N-\left(4-{ }^{11} C\right] m e t h o x y-3-m e t h o x y p h e n y l\right)-2-((5-$ methoxy-3H-imidazo[4,5-b]pyridin-2-

yl)thio)acetamide $\left(4-\left[{ }^{11} C\right] 4 a\right)$; 2-((6-amino-9H-purin8-yl)thio $)-N-\left(3-\left[{ }^{11} C\right]\right.$ methoxy-4-

methoxyphenyl)acetamide $\left.\left(3-\Gamma^{11} \mathrm{C}\right] 8 \mathrm{a}\right)$ and $2-((6-$ amino-9H-purin-8-yl)thio)- $N-\left(4-{ }^{I l} C\right]$ methoxy-3-

methoxyphenyl)acetamide $\left(4-\left[{ }^{1 l} \mathrm{C}\right] 8 \mathrm{a}\right):\left[{ }^{11} \mathrm{C}\right] \mathrm{CO}_{2}$ was produced by the ${ }^{14} \mathrm{~N}(\mathrm{p}, \alpha){ }^{11} \mathrm{C}$ nuclear reaction in the small volume $\left(9.5 \mathrm{~cm}^{3}\right)$ aluminum gas target provided 
with the Siemens RDS-111 Eclipse cyclotron. The target gas consisted of $1 \%$ oxygen in nitrogen purchased as a specialty gas from Praxair, Indianapolis, IN. Typical irradiations used for the development were $50 \mu \mathrm{A}$ beam current for $15 \mathrm{~min}$ on target. The production run produced approximately $25.9 \mathrm{GBq}$ of $\left[{ }^{11} \mathrm{C}\right] \mathrm{CO}_{2}$ at EOB. The phenolic hydroxyl precursor $4 \mathbf{b}$ (4c, $8 \mathbf{b}$ or $8 \mathbf{c})$ (0.1-0.3 $\mathrm{mg}$ ) was dissolved in $\mathrm{CH}_{3} \mathrm{CN}(300 \mu \mathrm{L})$. To this solution was added $2 \mathrm{~N}$ $\mathrm{NaOH}(2 \mu \mathrm{L})$. The mixture was transferred to a $5-\mathrm{mL}$ small reaction vial. No-carrier-added (high specific activity) $\left[{ }^{11} \mathrm{C}\right] \mathrm{CH}_{3} \mathrm{OTf}(13.9 \mathrm{GBq})$ that was produced by the gas-phase production method ${ }^{11}$ within $11 \mathrm{~min}$ from $\left[{ }^{11} \mathrm{C}\right] \mathrm{CO}_{2}(25.9 \mathrm{GBq})$ through $\left[{ }^{11} \mathrm{C}^{1} \mathrm{CH}_{4}(21.8\right.$ $\mathrm{GBq})$ and $\left[{ }^{11} \mathrm{C}\right] \mathrm{CH}_{3} \mathrm{Br}(13.9 \mathrm{GBq})$ with silver triflate (AgOTf) column was passed into the reaction vial at RT until radioactivity reached a maximum (2 min), and then the reaction vial was isolated and heated at $80^{\circ} \mathrm{C}$ for $3 \mathrm{~min}$. The contents of the reaction vial were diluted with $\mathrm{NaHCO}_{3}(0.1 \mathrm{M}, 1 \mathrm{~mL})$. The reaction vial was connected to a C-18 Plus Sep-Pak cartridge. The labeled product mixture solution was passed onto the cartridge for SPE purification by gas pressure. The cartridge was washed with $\mathrm{H}_{2} \mathrm{O}(2 \times 3 \mathrm{~mL})$, and the aqueous washing was discarded. The product was eluted from the cartridge with $\mathrm{EtOH}(2 \times 2 \mathrm{~mL})$, and then passed onto a rotatory evaporator. The solvent was removed by evaporation ( $3 \mathrm{~min}$ ) under vacuum. The final volume of ethanol after evaporation was $\sim 1$ $\mathrm{mL}$. The labeled product was reformulated with saline $(10 \mathrm{~mL})$, sterile-filtered through a sterile vented Millex-GS $0.22 \mu \mathrm{m}$ cellulose acetate membrane and collected into a sterile vial. Total radioactivity (4.7-7.1 $\mathrm{GBq})$ was assayed and the total volume (10-11 mL) was noted for tracer dose dispensing. The overall synthesis time including SPE purification and reformulation was $23 \mathrm{~min}$. The radiochemical yields decay corrected to $\mathrm{EOB}$, from $\left[{ }^{11} \mathrm{C}\right] \mathrm{CO}_{2}$, were 50$60 \%$. The same procedure was used to prepare the target tracers 3-[ $\left.{ }^{11} \mathrm{C}\right] \mathbf{4 a}$ and $4-\left[{ }^{11} \mathrm{C}\right] \mathbf{4 a}, 3-\left[{ }^{11} \mathrm{C}\right] \mathbf{8 a}$ and $4-\left[{ }^{11} \mathrm{C}\right] \mathbf{8 a}$ from their corresponding precursors $\mathbf{4 b}$ and $\mathbf{4 c}, 8 \mathbf{b}$ and 8c. Retention times in the analytical HPLC system were: $t_{R} \mathbf{4 b}=5.42 \mathrm{~min}, t_{R} \mathbf{4 c}=5.35 \mathrm{~min}, \mathrm{t}_{\mathrm{R}} \mathbf{4 a}$ $=7.74 \mathrm{~min}, \mathrm{t}_{\mathrm{R}} 3-\left[{ }^{11} \mathrm{C}\right] \mathbf{4 a}=7.85 \mathrm{~min}, \mathrm{t}_{\mathrm{R}} 4-\left[{ }^{11} \mathrm{C}\right] \mathbf{4 a}=$ $7.79 \mathrm{~min} ;$ and $\mathrm{t}_{\mathrm{R}} \mathbf{8 b}=3.57 \mathrm{~min}, \mathrm{t}_{\mathrm{R}} \mathbf{8 c}=3.46 \mathrm{~min}, \mathrm{t}_{\mathrm{R}} \mathbf{8 a}$ $=5.53 \mathrm{~min}, \mathrm{t}_{\mathrm{R}} 3-\left[{ }^{11} \mathrm{C}\right] \mathbf{8 a}=5.68 \mathrm{~min}, \mathrm{t}_{\mathrm{R}} 4-\left[{ }^{11} \mathrm{C}\right] \mathbf{8 a}=$ $5.61 \mathrm{~min}$. 